\title{
Insight
}

\section{Navigating the Back Loop: Fostering Social Innovation and Transformation in Ecosystem Management}

\author{
$\underline{\text { Reinette Biggs }}^{1,2}$ Frances R. Westley $^{3}$, and Stephen R. Carpenter ${ }^{1}$
}

\begin{abstract}
Addressing the environmental challenges of the $21^{\text {st }}$ century requires substantial changes to the way modern society views and manages ecosystems. In particular, many authors contend that fundamental transformation of the largely sectoral, expert-centered ecosystem-management institutions of modern, Western societies is needed. There is increasing agreement that more adaptive, integrated, collaborative ecosystem-management approaches, interlinked at multiple scales, would improve society's ability to sustainably manage complex social-ecological systems. Therefore, understanding processes of transformation, and factors that may enable transformation in ecosystem management, has become an active research area. We explore ecosystem-management transformations using a social-innovation framework. Based on three local-level case studies of transformation in freshwater management, we provide a pilot assessment of factors that may promote the emergence and adoption of integrated, collaborative ecosystem-management approaches. Our analysis suggests that ongoing environmental degradation, increasing environmental awareness, and shifting societal values are creating fertile ground for the emergence and adoption of new approaches to ecosystem management. Based on the case studies we examined, we suggest that initiatives that foster environmental awareness and attachment to local ecosystems, develop capacity for social entrepreneurship in the environmental arena, promote dialogue between key stakeholders, and provide institutional support to new institutions may facilitate the emergence of integrated, collaborative ecosystem-management approaches.
\end{abstract}

Key Words: adaptive cycle, bridging organization, co-management, complex systems, ecosystem management, social entrepeneur, social innovation, transformation

\section{INTRODUCTION}

Many ecosystems, at scales ranging from local to global, are now heavily human-influenced, and are undergoing large, far-reaching changes that threaten human well-being (Steffen et al. 2004, Millenium Ecosystem Assessment 2005, International Panel on Climate Change 2007). There is growing consensus that addressing this situation requires significant changes to the ways society views and manages ecosystems (Cortner and Moote 1999, Millenium Ecosystem Assessment 2005, WaltnerToews et al. 2008). Ecosystem-management institutions, including the processes, rules and structures for managing ecosystems (Ostrom 2005), are recognized as being in particular need of change. The centralized, sectoral, expert-centered approaches that have largely characterized ecosystem management in modern, Western contexts over the past century are increasingly recognized as insufficient for addressing many contemporary environmental challenges (Holling and Meffe 1996, Gunderson and Holling 2002, Walker and Salt 2006). There is growing agreement that ecosystem management, at multiple interlinked levels, needs to be transformed to more adaptive, integrated, collaborative approaches to improve environmental and social outcomes (Berkes et al. 2003, Dietz et al. 2003, Folke et al. 2005). Here, we explore factors that may help foster such a transformation in ecosystem management.

Shifts in beliefs about appropriate ecosystemmanagement institutions are related to changes in our understanding of how ecosystems function. Much of the $20^{\text {th }}$ century was dominated by the metaphor of ecosystems as complicated machines, suggesting that once their functioning was 
understood, policies could be designed to control and maintain ecosystems in some "optimal" state (Cortner and Moote 1999). We now have a different understanding of ecosystems. Rather than behaving as complicated machines, ecosystems are better understood as complex, evolving systems similar to living organisms (Levin 1998, Norberg and Cumming 2008). This view emphasizes that ecosystems are continuously evolving and changing. This change is sometimes slow and gradual and at other times large and rapid (Eldredge and Gould 1972, Holling and Gunderson 2002, Repetto 2006). Therefore, it shifts the focus of management away from attempting to maintain ecosystems in some fixed optimal state and instead focuses on guiding ecological change along desirable trajectories. Consequently, a complex systems perspective emphasizes the need for ongoing learning and continual re-evaluation and adaptation of ecosystem-management strategies (Walters 1986, Gunderson and Holling 2002, Chapin et al. 2009).

A complex systems view also highlights the importance of integrated, systemic approaches to ecosystem management. A distinguishing feature of complex systems is that they are defined more by the interactions among their constituent parts than by the parts themselves. Interactions among system components give rise to properties that cannot be predicted from the individual parts, a characteristic known as "emergence" (Holland 1999, Manson 2001). Given the strong interactions that exist between people and ecosystems, there is growing consensus that ecosystems are best understood and managed as coupled social-ecological systems (SES; Berkes and Folke 1998, Millenium Ecosystem Assessment 2005, Norberg and Cumming 2008). This suggests that although ecosystem management can draw on the information gained from sectoral expertise, it needs to adopt a systems approach that accounts for different sectors, as well as the ecological and social dimensions of ecosystems, in an integrated way.

Furthermore, it is becoming evident that the nature of complex systems poses inherent limitations on our ability to understand, predict, and control SES (Pilkey and Pilkey-Jarvis 2007, Roe and Baker 2007). Deciding on desired ecosystem outcomes, resolving trade-offs, and incorporating uncertainty and risk into decisions cannot be done through expert analysis alone, but require deliberation amongst relevant stakeholders (Cortner and Moote
1999, Bocking 2004, Millenium Ecosystem Assessment 2005). Growing awareness of the pervasiveness of uncertainty in complex systems calls for more participatory approaches to ecosystem management where those who have a stake in the ecosystem outcomes can participate in and contribute to decision making.

Encouragingly, there are several published examples of local-scale transformation from sectoral, expert-centered approaches to a more integrated, collaborative, adaptive forms of ecosystem management (Yaffee et al. 1996, Olsson et al. 2004). These examples may provide valuable insight into the conditions and processes necessary to stimulate transformation in ecosystemmanagement institutions in other regions and on larger scales. Many different frameworks can be used to understand processes of change in ecosystem management; for example, the punctuated equilibrium model (Repetto 2006), paradigm shifts (Kuhn 1970), the garbage can model (Cohen et al. 1972), and transition management (Rotmans et al. 2000, Loorbach 2007). Case studies of transformation have also been analyzed to identify different phases in the process of transformation (Olsson et al. 2004; 2006, Voss 2007). Here, we explore the analysis of transformative change in ecosystem management as a process of social innovation. A strength of the social-innovation framework is that it is founded on a complex systems view, and it not only describes processes of change, but also emphasizes the factors and leverage points that may foster the emergence of transformative change.

Our aim was to use a social-innovation framework to provide a pilot assessment of factors that may be leveraged to stimulate transformations in ecosystem management, from sectoral, expert-centered to adaptive, integrated, collaborative approaches. The social-innovation framework has not yet been applied to the question of transformation in ecosystem management, and may potentially provide some novel insights. Importantly, we do not attempt to provide a comparative assessment of the social-innovation framework relative to other frameworks for understanding change processes. Nor was it our intention to describe the change processes themselves in detail. Rather, our intention was to conduct an exploratory study using a social innovation framework to identify factors that might be leveraged to stimulate transformations in ecosystem management, thereby provide a starting 
point for more in-depth inquiries. Therefore, we have structured our discussion around potential key leverage factors and the relevant insights provided by each of the case studies, rather than around a detailed description of the transformation process in the individual studies as these have partly been documented elsewhere (e.g., Olsson et al. 2004).

\section{SOCIAL INNOVATION AND TRANSFORMATION}

Social innovation refers to new concepts, strategies, initiatives, products, processes, or organizations that meet pressing social needs and profoundly change the basic routines, resource and authority flows, or beliefs of the social system in which they arise (Westley et al. 2006, Young Foundation 2006). Social innovations can be pioneered by a wide range of actors, including NGOs, community groups, charities, governments, business, academics, philanthropists, or combinations of these groups. Innovation differs from invention in that it does not only refer to the creation of new ideas or products, but also to the processes of diffusion or adoption that make promising ideas useful in meeting social needs (Young Foundation 2006, McKeown 2008). Therefore, any process of social innovation consists of two dynamics: (1) "bricolage," or recombining existing and new ideas to form something novel (Levi-Strauss 1962, Arthur 2009), and (2) "contagion" or "diffusion," the adoption and spread of novel ideas or inventions (Rogers 1995, Westley et al. 2005, personal observations).

In the innovation field more broadly, two categories of innovation have been defined: (1) incremental innovation, and (2) radical innovation (McKeown 2008). Most innovation is incremental and represents evolutionary, stepwise improvements to existing ideas, products, or processes. Incremental innovation has a high chance of success and low uncertainty about outcomes. Radical innovation involves the development and adoption of new combinations of ideas, products, or processes that challenge or disrupt the broader institutional framework, whether it is social, cultural, political, or economic (Christensen et al. 2006). It requires larger leaps of understanding and often new ways of seeing a problem. The chances of success are difficult to estimate and there is initially often considerable opposition to such ideas (McKeown 2008). Social innovations are no exception. Both "routine" and "radical" forms of innovation are evident in social contexts, with the latter leading to profound changes in the systems in which they arise (Westley et al. 2006).

The relationship between incremental and radical innovation can be understood in terms of the adaptive cycle (Holling 2001, Gunderson and Holling 2002; Fig. 1). The front loop of the adaptive cycle can be seen as largely characterized by incremental innovation that strengthens the current system or trajectory of change. In contrast, the back loop may be precipitated by, or create a window of opportunity for, radical innovation. Changes and innovations that occur in the back loop may lead to fundamental reorganization of the SES, so that the system functions in a qualitatively different way than it did before, that is, it is transformed (Walker et al. 2004, Chapin et al. 2009). The uncertainties associated with the back loop may often provide a stimulus for innovation (Plowman et al. 2007).

Cross-scale effects are often important. Radical innovations at the local scale may cascade up, leading to transformations at larger scales, or vice versa (Holling et al. 2002). For example, the invention of modern agriculture fundamentally transformed SES at the global scale. The cumulative effect of individual incremental innovations may lead to radical innovation, as in the case of telephones and the internet. Similarly, transformative social innovations often occur through waves of individual innovations. For example, during the period of rapid industrialization and urbanization in $19^{\text {th }}$ century Europe, a huge upsurge in social innovation occurred, leading to the development of microcredit facilities, building societies, cooperatives, and trade unions that collectively met an array of new social needs and helped to transform society (Young Foundation 2006). A similar wave of innovation is needed if modern society is to transform its current ecosystem-management institutions to meet the environmental challenges of the $21^{\text {st }}$ century (Millenium Ecosystem Assessment 2005, Martin 2007, Waltner-Toews et al. 2008).

Much has been written on sources of innovation and enhancing the diffusion of innovations, especially in the business arena (Von Hippel 1988, Rogers 1995, Fagerberg et al. 2006). However, factors promoting social innovations are relatively unstudied. Available work suggests that social innovation is greatly facilitated by: (1) finance specifically directed at supporting innovation, (2) incubation processes that nurture promising innovations in their early stages, (3) leaders who visibly encourage and reward successful innovations, (4) the promotion of interactions across 
Fig.1. The adaptive cycle (Holling 2001, Gunderson and Holling 2002): a useful metaphor for understanding incremental and radical innovation in complex SES. $\dagger$ Adapted from Panarchy by Lance H. Gunderson and C. S. Holling, editors. Copyright (C) 2002 Island Press. Reproduced by permission of Island Press, Washington, D.C.

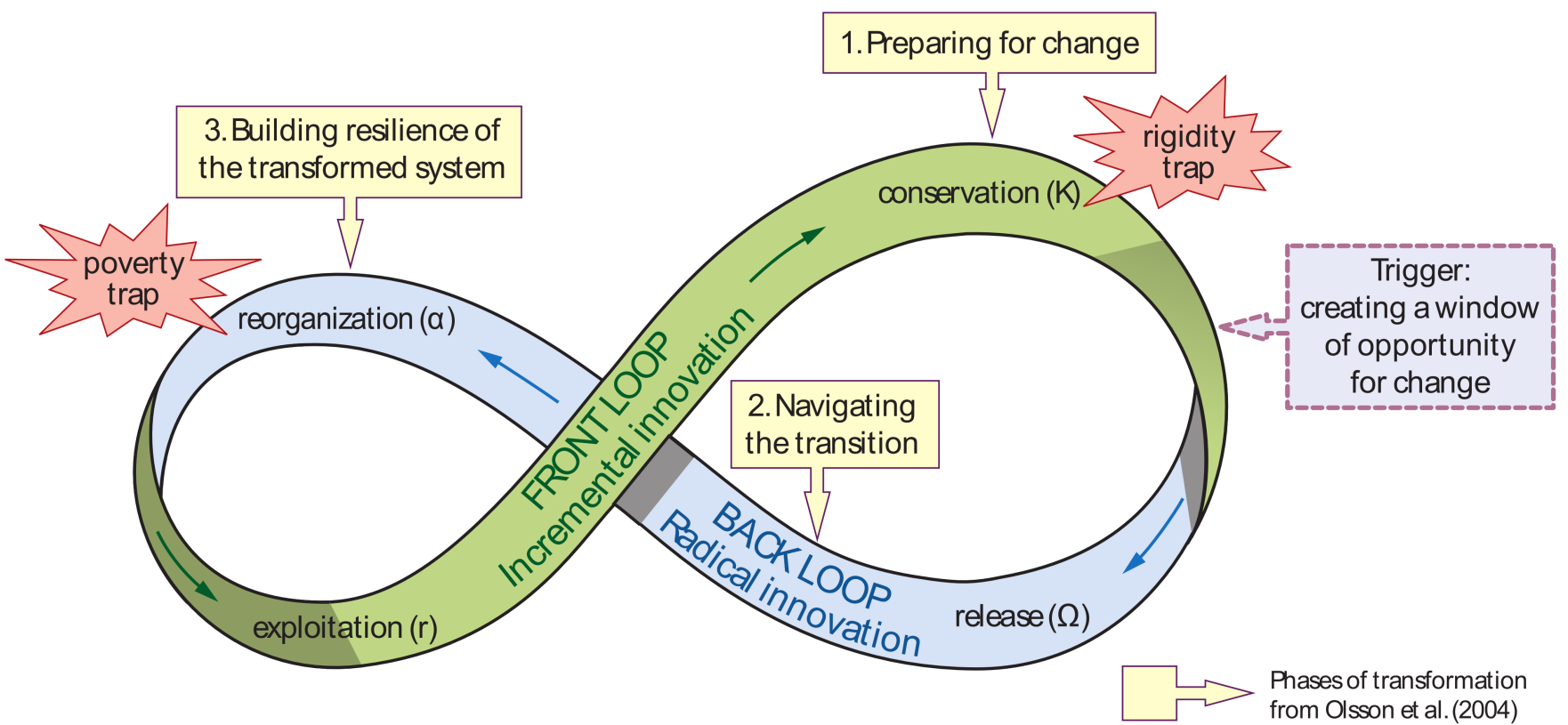

$\dagger$ The front loop of the adaptive cycle can be seen as largely characterized by incremental innovation, and the back loop is typically marked by radical innovation. Factors that trigger a switch from the front loop to the back loop often derive from processes operating at larger or smaller scales than that of the system of interest (Holling et al. 2002). "Traps" in the adaptive cycle may also be seen in the context of innovation. A "poverty trap" (stuck in the $\alpha$-phase) refers to a situation where the system is unable to move out of the back loop because of a lack of new ideas or an inability to choose an option and act upon it, given a lack of resources, for example. A "rigidity trap" (stuck in the K-phase) results from resistance to the adoption of new innovations because of, for example, large, rigid bureaucracies or powerful groups with vested interests (Miller 1993, Holling et al. 2002, Carpenter and Brock 2008). Boxes indicate the phases of transformation in ecosystem management identified by Olsson et al. (2004) that we have mapped onto the adaptive cycle.

organizational, sectoral, or disciplinary boundaries, (5) empowerment of users and stakeholders to drive innovation themselves, and (6) the opening of markets and governance processes to user groups and private businesses (Young Foundation 2006).

Importantly, social innovation cannot be directly planned and produced; it can only be stimulated by creating an environment conducive to the emergence of innovation. Like any innovative process, rates of success can be increased, but substantial failure rates for social innovations are to be expected (Westley et al. 2006, Young Foundation 2006, McKeown 2008). 


\section{METHODS}

The objective of this study was to use a social innovation perspective to explore factors that may foster transformation from a sectoral, expertcentered ecosystem-management approach, to a more adaptive, integrated, collaborative form of ecosystem management. We used an exploratory case-study approach (Yin 1994) to investigate this question. The exploratory case-study approach is appropriate where: (1) the goal is to develop hypotheses and propositions for further enquiry, (2) it is not possible to control the situation being investigated, for example, through experimental manipulation, and (3) a holistic approach that considers the interplay of factors in the richness of contemporary real-world contexts is required to understand "how" and "why" certain events occurred (Yin 1994, Stake 1995). Therefore, we did not predefine potential factors facilitating transformation but rather allowed them to emerge from the case studies. Importantly, results from such exploratory analyses should not be taken as conclusive. Detailed, rigorous, explanatory casestudy approaches are needed to firmly establish causal connections between conditions and events; that is, internal validity. The intention was that this pilot study would explore the usefulness of a socialinnovation perspective and would suggest starting points for more detailed case studies, rather than provide conclusive empirical findings.

To explore factors that may be leveraged to stimulate transformation in ecosystem management, we investigated three local-level case studies involving transformations in freshwater management: (1) the Kristianstad Vattenrike wetlands in southern Sweden, (2) the Sabie River in eastern South Africa, and (3) the Yahara Lakes near Madison, Wisconsin, USA. We focused specifically on factors that might promote "bricolage" and "diffusion," that is, the development and spread of social innovations in ecosystem management to identify potential leverage factors. We were particularly interested in the extent to which common factors could be identified across the three case studies, as these would suggest important initial research topics for more in-depth explanatory studies into policies that could help stimulate transformations in ecosystem management.

To broaden external validity and the potential applicability of our results, we selected case studies from three different regions of the world. Although all three cases represent modern, Westernized ecosystem-management contexts, their cultural and economic contexts differ markedly (Fig. 2). We have suggested that common factors identified as facilitating transformation across these three cases may be applicable in other countries with relatively developed economies and strong European heritages. All three case studies focused on transformations in freshwater management. The extent to which our findings may be applicable to ecosystem-management transformations in other contexts, and in other arenas such as biodiversity or agriculture, needs to be elucidated through further research.

In addition to geographic diversity, we selected the case studies based on their capacity to represent examples of local-scale transformation in ecosystem management, and the availability of information and interviewees. Given that we were interested in transformations from sectoral, expertcentered approaches to adaptive, collaborative, integrated approaches, all selected case studies had to show a change in this respect, and we took this change to be the central innovation of interest. The criteria for judging whether each case study qualified as an example of local-scale transformation in ecosystem management included whether: (1) a new named and identifiable entity, e.g., a bridging organization, emerged that facilitated much broader engagement and participation by stakeholders in ecosystem management, (2) the entity became the central coordinating body for ecosystem management in the particular region, linking disparate projects and groups and replacing a previous dominant authority or several sector-based authorities that were largely expert-based, (3) the entity explicitly adopted an integrated approach, implicitly or explicitly founded on a coupled social-ecological perspective and taking into account the interactions among different sectors, e.g., conservation and agriculture, (4) the entity displayed flexibility and adaptiveness in responding to changing environmental conditions or stakeholder interests, (5) the entity was deemed by most stakeholders to have had a significant impact in terms of improving local environmental conditions, or at least preventing further deterioration of environmental conditions, (6) the entity existed for at least a decade, and (7) the domain of influence of the entity was local in scale: sub-national, sub-state, or sub-provincial.

Our case-study approaches typically drew on a variety of information sources including interviews with actors, written records, and personal 
Fig. 2. Location and key statistics of the three case studies. $\dagger$

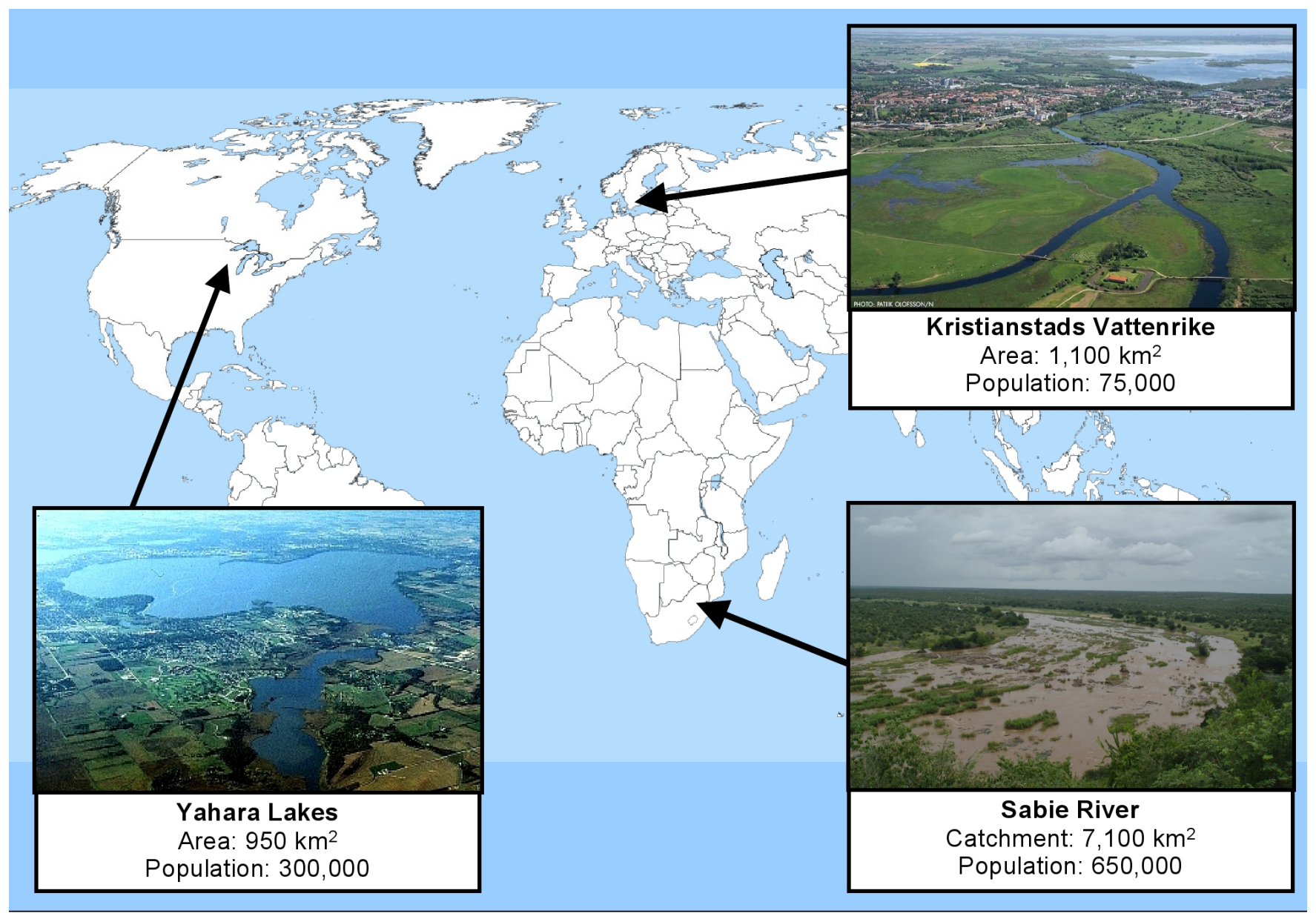

$\dagger$ The case studies show substantial cultural and economic diversity. Sweden is a relatively homogeneous society, as is the United States, whereas South Africa is highly multicultural. The United States has a strong capitalist and individualist ethic, whereas Sweden is a socialist society; South Africa lies somewhere between these extremes. In terms of economies, Sweden and the United States are both highly developed, and South Africa is a strong emerging economy (World Bank 2006). Population data are interpolated estimates for the watersheds for circa 2000.

$\ddagger$ Photo credits: Dick Lathrop, Patrick Olofsson, Rina Grant . 
observation. We investigated the process of social innovation in each case study based on the published literature and based on in-depth, open-ended interviews (Rubin and Rubin 1995, Kvale 1996) with 2-3 people knowledgeable about each case. We interviewed both researchers and ecosystem managers to gain different perspectives on the factors that were seen as important in enabling transformation. The interviews were recorded for referral and notes were made of points that were particularly emphasized by the interviewees. The interviews were conducted by asking interviewees to "tell the story" of how the new integrated, collaborative ecosystem-management approach came to be. This enabled interviewees to relate their understanding of the connections among events from their own particular mental frameworks rather than from the theoretical framework of social innovation. However, interviewees were asked to specifically highlight factors that were critical to: (1) coming up with the idea for the new entity, (2) establishing and maintaining the new entity, and (3) providing important obstacles to the establishment and maintenance of the new entity. The key common factors that appeared to facilitate transformation across the different case studies were synthesized and inferred based on these interviews and the literature about each case study. Where interviewees indicated an interest in reviewing the findings from the study, draft copies of the paper were provided and their comments were incorporated.

The written material for all three case studies was relatively limited. We attempted to gather and analyze all documents that reported on the case studies in any depth (Table 1). These documents were found through literature searches and through material identified and provided by the interviewees. As in the case of the interviews, in the written material we focused specifically on factors that were critical to: (1) coming up with the idea for the new entity, (2) establishing and maintaining the new entity, and (3) providing important obstacles to the establishment and maintenance of the new entity. Where the interviewees had authored or contributed to the written material, our understanding of the material was discussed and checked with the interviewees.

\section{OVERVIEW OF THE CASE STUDIES}

We introduce the ecosystem-management transformations that occurred in each of the case studies we examined, describe a set of key common factors that appeared to underlie innovation and transformation across the studies, and then discuss how these factors played out in each of the case studies. In all three of the case studies we explored, transformations in ecosystem management occurred through the establishment of bridging organizations during the late 1980s and early 1990s. Bridging organizations link actors at different levels and thereby facilitate interorganizational collaboration between, for example, government agencies, nongovernmental agencies, businesses, and community groups (Brown 1991, Westley and Vredenburg 1991, Olsson et al. 2007). The bridging organizations in the three case studies we explored were established to address the ongoing degradation of local freshwater ecosystems, and aimed to coordinate and integrate fragmentary individual ecosystem-management projects. In all three cases, the changes that occurred constituted a substantial reorganization in ecosystem management according to the criteria listed above and, therefore, were interpreted as examples of transformation (Walker et al. 2004, Chapin et al. 2009).

\section{Kristianstads Vattenrike, Sweden}

Kristianstads Vattenrike constitutes an extensive area of wetlands on the lower Helgea River surrounding the town of Kristianstad in southern Sweden. The wetlands provide valuable ecosystem services such as flood control, cultural and recreational values, and flooded meadows for grazing and haymaking. The wetlands also support a rich floral and faunal diversity (Olsson et al. 2004). Importantly, much of the wetland diversity is maintained by grazing and haymaking practices, making local people cultural stewards of the wildlife habitats (Nabhan 1997, Olsson et al. 2004).

Since the founding of the town in 1614, and especially after World War II, growing developmental pressures led to increasing degradation of the Kristianstad wetlands (Magnusson 1981). In an attempt to preserve the wetlands, a section of the area immediately adjacent to the Helgeå River was put on the Ramsar List of Wetlands of International Importance in 1975. This resulted in several conservation plans aimed at 
Table 1. Key literature sources used in each of the case studies.

\begin{tabular}{lll}
\hline \hline Kristianstads Vattenrike & Sabie River & Yahara Lakes \\
\hline Hahn et al. (2006) & Breen et al. (1995) & Born and Rumery (1989) \\
Olsson et al. (2004) & O'Keeffe and Rogers (2003) & Carpenter and Lathrop (1999) \\
Olsson et al. (2006) & Venter and Deacon (1995) & Carpenter et al. (2006) \\
Olsson (2007) & Venter et al. (2008) & Nakamura and Born (1993) \\
Schultz et al. (2007) & Unpublished box drafted by Freek & Lakes and Watershed Commission \\
Kristianstads Vattenrike website http://www. & Venter on the origins of the Sabie & website http://www.danewaters.com \\
vattenriket.kristianstad.se & River Working Group & \\
\hline
\end{tabular}

protecting the area from further exploitation. However, management of the wider Kristianstads Vattenrike remained uncoordinated, and despite its Ramsar designation, inventories and observations indicated that the natural and cultural values of the wetlands continued to be degraded. In particular, there was evidence of declining bird populations, eutrophication and overgrowth of the lakes, and a decrease in the use of flooded meadows for haymaking and grazing (Olsson et al. 2004).

In 1989, growing concern about the plight of the wetlands provided the impetus for establishing the Ecomuseum Kristianstads Vattenrike (EKV), largely through the efforts of a key visionary individual, Sven-Erik Magnusson (Olsson et al. 2004). The EKV acts as a bridging organization to facilitate and coordinate wetland-management activities (Hahn et al. 2006, Olsson et al. 2007). The EKV brought about a transformation in the management of the wetlands in three key respects: (1) it integrated conservation with economic and social development priorities and led to the development of a new identity for the town of Kristianstad, previously known as a military training center, (2) it provided a framework for linking previously fragmented and uncoordinated individual efforts to manage the wetlands, and (3) it initiated a process of collaborative management, creating a space for developing a common vision for the wetlands and addressing potential conflicts in a proactive manner. Institutionally, the EKV is part of the Kristianstad Municipality and reports directly to the municipality board, but has no authority to make or enforce legal rules (Olsson et al. 2004).

An important obstacle to the establishment of the EKV was the attitudes and values that residents had toward the wetland systems. The wetlands were largely perceived as a liability and a problem rather than an asset. In addition, lack of funding and conflicts among stakeholders threatened the viability of the EKV.

In June 2005, the Kristianstads Vattenrike became formally designated as a Biosphere Reserve under the Man and Biosphere Program of the United Nations Educational, Scientific and Cultural Organization (UNESCO). The EKV subsequently became known as the Kristianstads Vattenrike Biosphere Office and continues to play a highly active and influential role in managing the Kristianstads Vattenrike.

\section{Sabie River, South Africa}

The Sabie River is a perennial river in eastern South Africa, regarded as one of the country's flagship rivers because of its high aquatic diversity and good ecological condition (Venter and Deacon 1995, Council for Scientific and Industrial Research 2001, O'Keeffe and Rogers 2003). The upper catchment, or watershed, is intensively used for commercial timber plantations, and the central subtropical region supports commercial and subsistence irrigation. The central catchment is also heavily used for domestic water supply by impoverished rural communities. The lower catchment falls within Kruger National Park and associated private game reserves, constituting a premier tourist destination in South Africa (Council for Scientific and Industrial Research 2001). Therefore, upstream extractive uses of the river compete directly with downstream subsistence, tourism, and nonextractive conservation needs. 
In March 1992, increased withdrawals combined with a major drought led to some of the lowest flows ever recorded in the Sabie River. It was projected that the river would run completely dry by July/ August 1992 for the first time in recorded history (Venter and Deacon 1995). Given the high biodiversity value of the river, this situation was of significant concern to aquatic scientists in Kruger National Park. The situation was also of substantial concern to irrigation farmers and domestic water users. Prompted by their concerns, aquatic scientists in Kruger National Park called a meeting with the Sabie River Irrigation Board. Discussions resulted in the formation of a task team to investigate options for addressing concerns surrounding the drought, and subsequent stakeholder meetings led to the formation of the Sabie River Working Group (SRWG).

The SRWG acted as a bridging organization, transforming the existing management system by: (1) promoting dialog between the major stakeholders in the catchment, (2) providing a forum where a common vision and goals for the river were developed and agreed upon, and (3) providing an impetus for developing and implementing activities to realize this vision. The river management objectives developed by the SRWG focused on the fair distribution of water within the catchment, and preventing the river from drying up or becoming polluted within Kruger National Park. The different stakeholder groups proposed and carried out activities to realize these goals. These measures enabled the SRWG to meet its objectives, and the river did not stop flowing (O'Keeffe and Rogers 2003).

Conflicts among stakeholders, especially those involved in agriculture and forestry, were an important obstacle to the establishment of the SRWG. Much of this conflict revolved around differing perspectives and a lack of agreement about the impact of activities such as forestry on river flow.

The SRWG remained active as a coordinator and facilitator of activities in the catchment for about a decade after its formation. The group was eventually disbanded during attempts to establish the Inkomati Catchment Management Agency (CMA), a government-initiated agency that is to fulfill similar functions to the SRWG, mandated by new environmental legislation. However, the Inkomati CMA has yet to become operational, and the disbanding of the SRWG has created a significant vacuum in the coordination of activities in the catchment.

\section{Yahara Lakes, Wisconsin, USA}

The Yahara Lakes-Mendota, Monona, Waubesa and Kegonsa-and their catchments lie almost entirely in Dane County, Wisconsin. Much of the watershed is urbanized, and the shorelines of Lakes Mendota and Monona are distinctive features of downtown Madison, the state capital. The lakes are heavily used for water-based recreation and have high aesthetic value. With the University of Wisconsin situated on the shores of Lake Mendota, they are also among the most studied lakes in the world (Brock 1985, Kitchell 1992, Carpenter 2003). The remainder of the Yahara watershed is mainly used for agriculture. Phosphorous runoff, primarily from urban construction sites and agricultural fields, is a major contemporary cause of algal blooms in the lakes, leading to fish kills, affecting recreational activities, producing a nasty smell, and increasing the costs of water purification (Carpenter et al. 2006). Therefore, valued ecosystem services are compromised by the side effects of agriculture and expanding urbanization.

The area was settled in the 1830s, and noxious algal blooms and fish kills were regularly reported on in the Yahara Lakes beginning in the 1880s (Brock 1985). Initially, the main causes of the eutrophication were runoff from cleared agricultural lands and raw sewage Verify that the meaning has not been changed. Initiatives to divert sewage were active from the 1940s through the 1960s, and all sewage was diverted to sewage treatment plants by 1971 (Carpenter et al. 2006). However, nonpoint phosphorous pollution from fertilizer runoff and urban construction sites led to ongoing eutrophication problems. As of 1975, the Dane County Regional Planning Commission began preparing plans to control nonpoint pollution, but action was limited (Carpenter and Lathrop 1999). In 1980, the western half of Lake Mendota's drainage basin (Sixmile-Pheasant Branch Creeks) was designated as a priority watershed project by the Wisconsin Department of Natural Resources, allowing state funds to be used to share the cost of nonpoint pollution reductions with individual landowners and municipalities. However, voluntary participation by landowners was minimal, and many of the management practices turned out to be 
ineffective at reducing phosphorous inputs (Carpenter and Lathrop 1999).

To more effectively address the ongoing waterquality problems in the Yahara Lakes, the Dane County Board created the Dane County Lakes and Watershed Commission (LWC) in 1988. The LWC was intended to integrate fragmented watershedmanagement activities, and was empowered to improve water-quality and the scenic, economic, recreational, and environmental value of the county's water resources (Carpenter et al. 2006). The LWC can recommend programs, plans, and projects to the County Board for approval, and can insist that minimum standards be passed for waterquality benefits. The establishment of the LWC represented a transformation in the management of the Yahara Lakes in the following respects: (1) it helped refocus efforts to manage water-quality to account for activities in the entire watershed, rather than only focusing on in-lake management, (2) it provided a means for integrating fragmented efforts relating to the management of the Yahara Lakes and their watersheds, and (3) it allowed for formal representation of stakeholders and provided forums where the public could give input on lakemanagement issues (Born and Rumery 1989, Nakamura and Born 1993). Although public participation had been emphasized before the LWC, the myriad governmental entities previously responsible for water-related management made effective public participation in decision-making processes difficult (Nakamura and Born 1993). However, important obstacles in the formation and operation of the LWC were engaging different stakeholders and authorities, and building support and appreciation for issues that transcended the narrow interests of each group.

As of 2008, the LWC continued to play an active role in coordinating freshwater management in the Yahara Lakes district. However, there are concerns that the LWC is preoccupied with short-term crises (e.g., restricting boat speeds to prevent flooding of shoreline houses because of high water levels), rather than focusing on long-term strategic issues, such as the risk of alien invasives and the potential consequences of climate change.

\section{KEY FACTORS UNDERLYING INNOVATION ACROSS THE CASE STUDIES}

Based on the literature and interviews, we identified important factors contributing to innovation and transformation in each of the case studies. We grouped these factors along three dimensions: (1) the trigger or impetus for innovation, (2) "bricolage" and the sources of new ideas and approaches, and (3) "diffusion," whereby new ideas and approaches became adopted and implemented (Table 2). As is evident from the case studies, these dimensions seldom occur in sequence. Rather, they tend to occur concurrently with multiple iterations among the different components (Born and Genskow 2000, Wondolleck and Yaffee 2000, Young Foundation 2006).

Based on Table 2 and our interviews, we identified the following key common factors underlying transformation in ecosystem management across the three case studies: (1) environmental crises, (2) reframing of perspectives, (3) engaging stakeholders, (4) social entrepreneurship, and (5) institutional support. These findings corroborate existing work in diverse fields. What our analysis adds is to emphasize specifically how these factors may stimulate social innovation and transformation in ecosystem management, and to provide a starting point for more in-depth analyses of how and under which conditions these factors might be leveraged.

\section{Environmental Crises}

Environmental crises are abrupt or ongoing environmental changes that have negative implications for human well-being. In all three case studies, ongoing and anticipated future environmental degradation appears to have been the major impetus for developing and adopting new approaches to ecosystem management (e.g., Table 3, Quote A). This observation confirms work by other authors who suggest that ecosystem-management changes are often triggered by environmental crises (Plummer and Fitzgibbon 2004, Folke et al. 2005). However, in the case studies we examined, degradation itself appeared insufficient for precipitating changes in the management approach, as least initially. It seems that at least two additional factors were necessary before alternative approaches to ecosystem management were adopted. 
Table 2. Key factors that triggered social innovation in ecosystem management, acted as sources of ideas for alternative management approaches (bricolage), and facilitated diffusion of new approaches (contagion) in each of the case studies.

\begin{tabular}{ll}
\hline \hline & Kristianstads Vattenrike \\
\hline $\begin{array}{l}\text { Impetus for } \\
\text { innovation }\end{array}$ & $\begin{array}{l}\text { Ongoing degradation of the } \\
\text { wetland environment with } \\
\text { declining bird populations, } \\
\text { eutrophication, and loss of } \\
\text { flooded meadows. }\end{array}$ \\
& $\begin{array}{l}\text { Increasing environmental } \\
\text { awareness among the public, } \\
\text { partly associated with the death of } \\
\text { seals along the coast. }\end{array}$
\end{tabular}

Need to revive the town's identity and local economy following its decline as a military training center.

Bricolage: sources of alternative ideas and approaches

Contagion: adoption and diffusion of new ideas (amarguais an the UNESCO Man and Biosphere Reserves provided inspiration for alternative, more integrated, management approaches.

Failure of existing approaches, such as Ramsar Wetland designation, highlighted the need for more integrated approaches.

The knowledge and experience of different groups and agencies active in wetland conservation.

Visionary leadership was critical to developing the new approach, gaining support for the approach, and providing the ongoing drive
Sabie River

Major drought that was projected to lead to the first-ever cessation of flow in the Sabie River.

Ongoing increases in withdrawals, threatening future river flow.

Increasing awareness of the value of the Sabie River in terms of its aquatic diversity and relatively unimpacted state.

Growing ecological to get it implemented.

Engaging stakeholders and gaining their support, largely through one-on-one meetings where the new approach was framed in ways that the different stakeholders could relate to, was critical to the adoption of the new approach.

Institutional support from the municipality ensured continuity and support for core staff. understanding (especially associated with the Kruger Park Rivers Research Programme) increased appreciation of the need for systemic approaches to river conservation. the different stakeholders enabled identification of actions to improve river flow without jeopardizing livelihoods, e.g., ringbarking riparian invasives, allocation of irrigation withdrawals.

Social entrepreneurship and leadership was central to engaging stakeholders and managing conflict among stakeholders.

Field trips and social activities (e. g., barbequing) were central to building understanding of different stakeholder needs and a team spirit of shared commitment to goals.

Developing commonly agreed upon objectives and goals for river management, supported by all key stakeholders, was central to adopting and implementing new management approaches.
The sector-specific knowledge of
Yahara Lakes

Ongoing eutrophication problems related to phosphorous runoff from agricultural fields and urban construction sites.

Fragmentation of management activities and relating to lake management.

Designation of priority watersheds and influx of associated funding.

Scientific expertise associated with the University of Wisconsin and the Wisconsin Department of Natural Resources.

Entrepreneurship and committed leadership and political know-how was central to developing a politically acceptable new management approach.

Provision for representation on the new commission by key interest groups was central to making it politically acceptable.

Institutional support from Dane County has enabled continuity of the new commission and support of core staff.

Granting of advisory powers to the commission strengthened it. 
Table 3. Illustrative quotes highlighting factors facilitating transformation in the case studies.

\begin{tabular}{ll}
\hline \hline Factor & Illustrative quote \\
\hline Environmental crises & $\begin{array}{l}\text { [Quote A] "Projections showed that the river would stop flowing completely by July or August of } \\
\text { that year if no correctional actions were taken. This was almost incomprehensible as the Sabie River } \\
\text { was well known for its high biodiversity [at that stage it was hailed as the most biodiverse river in } \\
\text { South Africa] that was dependent on flowing water as habitat and was seen as a flagship of South } \\
\text { African rivers." (Sabie River) }\end{array}$
\end{tabular}

Fragmentation [Quote B] "Prior to 1988, the DNR [Department of Natural Resources] and RPC [Dane County Regional Planning Commission] were primarily responsible for coordinating water quality management through a county water-quality plan...Watershed management consisted of numerous separate programs and actions carried out over time by different entities. Also, the DNR was responsible for in-lake management while municipalities and the county were responsible for shorelines, surface waters, and runoff." (Nakamura and Born 1993; Yahara Lakes)

Reframing perspectives

Engaging stakeholders

Leadership and social entrepreneurship
[Quote C] "Previously I was almost afraid of the authorities, it felt so bureaucratic somehow. But thanks to this project I have learned a lot and I have a completely different view now. It's more like we all sit in the same boat." (Hahn et al. 2006; Kristianstads Vattenrike)

[Quote D] "SEM [Sven-Erik Magnusson] presented the area in a different way than anyone had done before and I became aware of the values. Many considered the wetlands as a problem...SEM presented a nature conservancy plan that didn't close the area but opened it up and made it accessible for the public" (Olsson et al. 2004; Kristianstads Vattenrike)

[Quote E] "Having talked to so many people out in the district, we realize that bombs might be dropped if we were to bring everybody together for a large meeting. I mean, you don't gather people if you don't think anything positive will come out of the meeting." (Hahn et al. 2006; Kristianstad Vattenrike)

[Quote F] "The key was to avoid a one-size-fits-all proposal that would be so neutral that nobody would be interested. Instead, I [Sven-Erik Magnusson] had to approach each person and identify what their specific needs and interests might be and emphasize the parts of the [EKV] project proposal that they could identify with and find of interest." (Olsson et al. 2004; Kristianstad Vattenrike)

[Quote G] "The "esprit de corps" that formed in the SRWG was partly achieved by organizing field days in the respective areas and hosted by the different sectors. Meetings were held biannually under the trees at the Kruger Gate gauging weir and delegates were treated with some beers, soft drinks and a braai [barbeque] afterwards." (Sabie River)

[Quote H] "Initially, there was considerable conflict, especially between the irrigation and forestry sectors, which accused each other of unsustainable practices. Outstanding leadership and fostering the notion that we are all together in the catchment and cannot wish each other away eventually led to a cohesive committee as rivalry made way for practical jokes. Friendships that were molded in those years still last up to this day." (Sabie River)
First, the value of the ecological attributes being lost and their connections to human activities had to become appreciated. In all three studies, this growth in awareness seems to have been a gradual process involving a complex interplay between increased ecological understanding and changing societal values. Second, transformation did not occur until it became apparent that existing approaches, or incremental modification to existing approaches, did not adequately address the degradation. For example, the initial response to wetland degradation around Kristianstad was to protect the wetlands through designation as a Ramsar wetland site, a response that fitted the sectoral approaches of the day. It then took more than a decade to "test" this intervention, realize its inadequacies, and initiate an 
alternative response in the form of the EKV (Olsson et al. 2004). In the Yahara Lakes case, incremental responses to environmental issues led to a large proliferation of agencies and programs responsible for water-related issues, but with no mechanism for coordination among these agencies (Table 3, Quote B). Alternative approaches were sought only once it became clear that this was untenable and limiting the effective management of the lakes (Born and Rumery 1989, Nakamura and Born 1993).

Nevertheless, all three case studies displayed a substantial degree of proactiveness in identifying and addressing environmental situations that would likely have led to considerable conflict and acrimony if they had been left unaddressed. Encouragingly, this suggests that actors are able to initiate and mobilize management changes based on information that serious problems may be looming, without experiencing such problems first-hand. Based on the interviews we conducted, we speculate that ecosystem-management transformations may be more likely, and are more likely to be lasting, if initiated before high levels of conflict set in. It is well known that once strong feelings of acrimony exist, people tend to become locked into defensive positions (Kahane 2004, Tavris and Aronson 2007). Initiating dialog and developing and implementing new approaches to ecosystem management may then become substantially more difficult (HomerDixon 1995, Kofinas and Griggs 1996, Olsson 2007).

\section{Reframing of Perspectives}

A "frame" in social theory consists of a schema of interpretation, that is, a collection of anecdotes and stereotypes that individuals rely on to understand, interpret, and respond to events (Goffman 1974). Reframing involves seeing a context or situation in a new and different way that often enables new possibilities to emerge. In the case studies we examined, reframing of perspectives appeared central to the emergence of approaches that transformed ecosystem management. In all three cases, changes in stakeholder perspectives seem to have been substantially informed by new ecological understanding. For example, it was not until the 1960s that the link between phosphorus in agricultural fertilizers and freshwater eutrophication became firmly established scientifically (Schindler 2006). In the case of the Yahara Lakes, understanding the connections between activities in the watershed and in-lake water-quality problems was central to identifying the need for management at the watershed level rather than simply at the lake level. The newly recognized need for watershedlevel management was central to the development of the initial idea for the LWC and the drive to establish it (Born and Rumery 1989).

Reframing of perspectives in the case studies also appears to have been greatly influenced by more diffuse processes of growing environmental awareness and changing societal values. Increasing environmental awareness globally and associated changes in societal values through the 1960s and 1970s (e.g., Carson 1962, Ehrlich 1968, Meadows et al. 1972) appears to have made stakeholders in the different studies more receptive to new management initiatives focused on improving environmental quality. For example, in the case of Kristianstad, media attention highlighting the death of seals along the Swedish coast in the late 1980s was specifically noted as helping to create a receptive environment for discussions on establishing the EKV (Olsson 2007).

More directly, stakeholder perspectives seem to have been influenced by exposure to the local ecosystems and informal interaction with other stakeholder groups. For example, interviewees in the Sabie River case study identified field trips as a critical success factor in the development of the SRWG. During these field trips, irrigation farmers, forestry representatives, and other stakeholders were taken out to a section of the Sabie River in Kruger National Park where they electrofished and collected macroinvertebrates. Interesting and unique aspects of the ecology were highlighted in an informal and enjoyable way. Similar outings were arranged by the forestry and irrigation sectors to highlight the ways in which they used and cared for the river system. These outings were seen as critical to building an appreciation and understanding of the different stakeholders' needs, and fostering an attachment to the river ecosystem. Similar field trips and a river boat cruise in the Kristianstad wetlands were noted as having played an analogous role in reframing perspectives and shifting values in that study (e.g., Table 3, Quote C).

At a more fundamental level, reframing the idea of environmental conservation itself seems to have been a critical factor enabling the emergence of alternative management approaches, especially in the Kristianstad case. Before the establishment of 
the EKV, conservation in the Kristianstad region was largely seen as involving wetland protection but excluding the human influence. A crucial factor in convincing the Kristianstad Municipality to establish the EKV was that it proposed to link conservation to economic and social development priorities. The wetlands were reframed as being an asset rather than a problem, so that the region became seen as "water rich" as opposed to "water sick" (Olsson et al. 2004). The stated vision of the EKV was to open the wetlands up for human use and enjoyment rather than excluding people (Table 3, Quote D). Reframing conservation in a way that integrated economic and social imperatives and recognized and incorporated human use of ecosystems was also a distinguishing feature in the establishment of the LWC and the SRWG.

Lastly, the Kristianstad case study suggests that role models of integrated, collaborative ecosystem management can be important as a source of inspiration for developing alternative ecosystemmanagement approaches. Magnusson was much inspired by the French "Musée Camarguais" and the UNESCO Man and Biosphere Program to develop the original proposal for the EKV (Olsson et al. 2004).

\section{Engaging Stakeholders}

Stakeholder engagement refers to the process of engaging people with a stake in a particular decision in the process of decision making, taking into account their varying perspectives, priorities, and limitations. In all three case studies, the engagement of key stakeholders appears to have been central to developing new approaches to ecosystem management and enabling these ideas to be successfully implemented. Stakeholders included key groups impacting or impacted by changes in the local ecosystem, as well as various fragmentary groups carrying out conservation and management efforts. A simple, compelling focus seems to be important in initially engaging stakeholders and enabling a collaborative group to form and "gel." For example, in the Sabie River case, preventing the river from running dry provided a clear issue for approaching different stakeholders and initiating discussions. Once the group had formed, it was possible to develop more complicated and diverse foci. Similarly, discussions leading up to the formation of the LWC focused primarily on water- quality management (Born and Rumery 1989), but over time the LWC adopted additional foci such as control of non-native species.

Several interviewees noted specifically that successfully engaging stakeholders does not simply involve inviting everyone who may be interested in a particular issue to a meeting (e.g., Table 3, Quote E). Rather, different stakeholder groups are initially best approached individually, so that discussions can be framed in terms that speak to the concerns and needs of the different groups. The development of the EKV provides a very clear example of this approach. After coming up with the initial idea for the EKV, Magnusson garnered support by approaching receptive, strong individuals in key organizations (Table 3, Quote F). Over time, close relationships and trust with these individuals was established, and only once Magnusson had incorporated their ideas into the EKV proposal and had their support did he involve a broader spectrum of stakeholders (Olsson et al. 2004, Olsson 2007). This "starting small" approach remains a key strategy of the EKV when starting new projects. It also supports the well-established finding that innovative new ideas need initial nurturing if they are to grow (Young Foundation 2006, McKeown 2008).

Once collaborative groups in the different case studies had formed and agreed on a set of objectives, the experiences and perspectives that different stakeholders brought to the table played an important role in developing and implementing strategies for meeting the groups' objectives. For example, to achieve the agreed-upon goal of preventing the Sabie River from running dry, the forestry sector in the region volunteered to remove "runaway" exotic trees in the riparian zone of the river's upper reaches, while irrigators voluntarily developed and implemented water restrictions that were subsequently adopted and promulgated by the Department of Water Affairs and Forestry (O'Keeffe and Rogers 2003). Interviewees in the Sabie River case felt that the development of a "team spirit" was central to motivating the different actors to generate and voluntarily implement such ideas. As mentioned, field trips, that also involved barbequing and drinking beer, were believed to be central in building the trust and respect that enabled a team spirit to emerge (Table 3, Quote G). As found by other authors (Born and Genskow 2001), discussing and developing organizational rules for 
the functioning of the group also appeared to play an important role in the development of group cohesion in the different case studies.

In the LWC, the possibility for engaging key stakeholders has arguably been partly compromised by overformalizing the processes by which the group operates. Rather than constituting a voluntary association of interested and concerned groups and individuals, the LWC is a formal commission to which members are appointed. Membership is limited to 10 people who represent specific rural and urban constituencies. Although this may ensure that the views of certain groups are not excluded, it makes the LWC somewhat inflexible with regard to engaging new groups or individuals that become relevant or interested to contribute to the work of the LWC. An overformalized structure may also compromise learning and innovation, and many authors have found that new ideas and collaboration are best generated in trustful, informal settings (Westley and Vredenburg 1997, Hahn et al. 2006, McKeown 2008).

\section{Social Entrepreneurship}

A social entrepreneur is someone who recognizes a social problem and uses entrepreneurial principles to organize, create, and manage an initiative to bring about social change (Leadbeater 1997, Bornstein 2004). Social entrepreneurship was a critical element in the development of new management approaches in all three case studies, supporting a large body of existing work on the importance of leadership and entrepreneurship in transformation (Born and Genskow 2001, Folke et al. 2005, Olsson et al. 2006, Westley et al. 2006). In the studies we examined, social entrepreneurship played a particularly important role in three respects: (1) reframing perspectives, especially by providing or facilitating the development of an alternative vision for ecosystem management, (2) engaging key stakeholders by fostering a group identity and building networks, and (3) managing conflict. These functions were often performed by the same individual but in some cases were dispersed across several individuals.

Because (1) and (2) have largely been covered in the above discussion, we focus here on conflict management. Tensions between the perspectives and needs of different stakeholders are often a key source of new ideas and approaches. For example, the need to integrate conservation with economic and social development needs was central to the development of the EKV approach. However, if not appropriately managed, conflicts can forestall the development and spread of new approaches and ideas (Kofinas and Griggs 1996, Olsson 2007). In the Sabie River case study, for example, there was substantial antagonism between the forestry and irrigation sectors during the initial meetings (Table 3, Quote H). Despite established evidence that exotic timber plantations substantially reduce runoff (Wicht 1949, Hewlett and Hibbert 1961, Smith and Scott 1992), representatives of the forestry sector maintained that the plantations in fact improved runoff. The chairman of the group, Japie Lubbe, is credited with managing the impasse and enabling agreement to be reached on the major factors impacting river flow. Only once consensus was attained in this respect could options for reducing impacts be productively explored.

In terms of building networks and diffusing ideas, we add that entrepreneurs in the different case studies acted as key nodes linking a variety of local networks. Individuals that performed key leadership and entrepreneurial functions were typically involved in similar roles in several other networks. For example, Shary Bisgard, an initiator and early chair of the LWC, was also actively involved in several other citizen and county groups, such as neighborhood associations and countyplanning boards. At any one time, as well as through their movement between groups over time, such individuals create links among groups and function as a vehicle for diffusion of ideas from one group to another (Janssen et al. 2006, Westley et al. 2006).

\section{Institutional Support}

Institutional support refers to support for day-today operational activities of an institution, such as finance, personnel, management, planning, and office space. In the three case studies we examined, institutional support, and specifically governmental support, appeared to be a key factor enabling the bridging organizations to become established. In the case of the EKV and the LWC, the organizations are formally housed by the local government, who provide salaries and office space for a small core staff. Such assured funding, especially for managing administrative and organizational aspects of bridging organizations, has been found to be central to their maintenance over time (Born and Genskow 
2001, Young Foundation 2006). Links to and support from government also provide a potential mechanism for diffusion of ideas and activities of the bridging organizations to other areas and groups (Young Foundation 2006).

However, the Sabie River case illustrates that government can also inadvertently squash grassroots-initiated bridging organizations. Initially, the Department of Water Affairs and Forestry was very supportive of the activities of the SRWG. However, new legislation introduced in 1998 (Republic of South Africa 1998) mandated the establishment of Catchment Management Agencies (CMAs) for all major catchments in South Africa. These agencies are to contain representatives from all major stakeholder groups, and are empowered to make decisions about local water allocation and to perform various bridging functions in managing local river systems. The legislation is widely heralded as visionary (Postel and Richter 2003, Gowlland-Gualtieri 2007) and is based on contemporary understanding of complex systems and values espousing stakeholder participation and empowerment. However, it is widely held that the organizational culture of the Department is poorly matched to facilitating the establishment of these agencies (Rogers et al. 2000) and, in addition, the Department is faced with serious capacity constraints. Attempts to establish the Inkomati CMA for the Sabie River led to the disbanding of the SRWG, and the subsequent faltering of the process is a source of much frustration.

\section{IMPLICATIONS: WHAT STRATEGIES MIGHT FOSTER A WAVE OF INNOVATION IN ECOSYSTEM MANAGEMENT?}

In many respects, society at the global scale can be interpreted as poised for, or perhaps already undergoing, a major back loop (Gray 1995, Steffen et al.2004, Constanza et al.2007). Environmentally, many of the approaches and practices that characterized the modern, industrial era of the last 300 years or so are now widely regarded as unsustainable and in need of fundamental reorganization (Steffen et al. 2004, Millennium Ecosystem Assessment 2005, Intergovernmental Panel on Climate Change 2007). Furthermore, although these are often overlooked, dramatic changes in attitudes toward the environment, support for inclusive, democratic practices, and beliefs about the ability and role of science in society have occurred over the past half century (Funtowicz and Ravetz 1993, Gray 1995, Cortner and Moote 1999, Ziman 2000). Our case studies suggest that these conditions may create fertile ground for radical social innovation. We have attempted to explore what factors might be leveraged to bring about a large-scale transformation in ecosystem management.

Applying a social-innovation framework emphasizes that environments conducive to the development of alternative ideas for ecosystem management, as well as conditions that nurture such ideas and allow them to take root, are critical to enabling transformation in ecosystem management. Based on the case studies we examined, we suggest that the following strategies may help create environments that enable new ideas for ecosystem management to emerge and flourish, at least at the local scale. How and under which conditions such strategies may best be implemented need to be examined using more detailed explanatory casestudy approaches.

\section{Foster environmental awareness and attachment to local ecosystems}

Our interviews highlighted that leaders who spearhead transformations are often greatly motivated by an awareness and understanding of the unique aspects of the ecosystems they seek to have better governed, and often feel a deep attachment to these ecosystems. In many cases, such attachment started forming during the leaders' youths. Additionally, our case studies indicate that stakeholders become substantially more open to changes in ecosystem management, often at a cost to themselves, once they become aware of the value of the local ecosystems and have personally experienced these environments. Therefore, we suggest that fostering awareness and attachment to local ecosystems among both adults and youths may directly and indirectly contribute to increased rates of social innovation in ecosystem management. This supports work by other authors (Vredenburg and Westley 1997).

Our case studies suggest that environmental awareness and attachment to this end may be best fostered through informal, experiential activities that take place within the setting of the local ecosystem (e.g., Table 3, Quote G). Our interviews also point to the importance of access to local ecosystems in building support for their 
conservation (e.g., Table 3, Quote D). Although many environmental awareness activities already exist, it is clear that there is substantial scope for expanding interaction with local ecosystems in modern societies (Louv 2008). Our exploratory work suggests that better understanding how environmental awareness and attachment to local ecosystems may best be fostered and supported, and the impact it has on individuals and societies, is an important area for further research.

\section{Build capacity for social entrepreneurship}

As in our case studies, social entrepreneurship and leadership have widely been found to be critical to transformation processes (Born and Genskow 2001, Olsson et al. 2004). The nature, effectiveness, and development of leadership and social entrepreneurship is an area that has received much attention, especially in the business literature (Lewin et al. 1939, Greenleaf 1977, Burns 1978, House and Podsakoff 2003, McCauley and Van Velsor 2003). Studies have shown that personality traits strongly influence an individual's entrepreneurial ability (McCauley and Van Velsor 2003), although most people can develop their effectiveness through focus, practice, and persistence (McCauley and Van Velsor 2003, Carter et al. 2004) and many programs exist to meet this need. However, relatively few programs focus specifically on developing leadership and social entrepreneurship in the environmental arena.

Promoting integrated, collaborative, adaptive environmental management requires democratic or servant leadership, where all parties contribute to and take ownership of key decisions (Lewin et al. 1939, Greenleaf 1977), as well as social entrepreneurship, i.e., the ability to recognize a social problem and use entrepreneurial principles to organize, create, and manage a venture to address the problem (Bornstein 2004, Leadbeater 1997). Key strategies employed by successful social entrepreneurs include: (1) building and amplifying networks of individuals and organizations relevant to the problem, (2) dispersing power, for example, by involving people such as technicians who have low formal status but hold knowledge critical to the problem, and (3) avoiding centralized control and structuring (Westley 1997, Westley and Vredenburg 1997). We suggest that developing and expanding programs that focus specifically on developing leadership and entrepreneurial capacity for collaborative problem solving around environmental issues could give a substantial boost to social innovation in environmental management. Identifying the important elements of such a program represents another important area for further investigation.

Our case studies also suggest that transformation could potentially be leveraged by identifying and supporting key, established, innovative individuals already performing leadership functions in support of environmental-management transformations in a particular region. As is evident from our case studies, such individuals have well-established, extensive networks, and act as key links between disparate groups and initiatives. Providing key individuals with financial and institutional support, and giving them relative carte blanche to initiate and carry out activities is increasingly adopted as a strategy for enhancing innovation (Westley et al. 2006, Young Foundation 2006, McKeown 2008).

\section{Foster dialog between key stakeholders}

Our case studies suggest that dialog between key stakeholders is a critical precursor to the establishment of integrated, collaborative ecosystemmanagement institutions. Our studies also indicate that simply inviting all stakeholders to a few joint meetings is usually insufficient for achieving the generative dialog that enables new ideas to emerge and grow (e.g., Table 3, Quote E). Much recent work can be drawn upon to promote more productive dialog between parties with conflicting interests (Gray 1989, Isaacs 1999, Kahane 2004, Senge et al. 2004). This work stresses the need to first acknowledge and explore the perspectives and needs of the different parties. Then, rather than seeking to negotiate a compromise among the initially articulated needs of the different parties, the emphasis is on reframing the situation away from one of conflict to one of common interests and challenges (Wondolleck and Yaffee 2000, Rogers 2006). Such reframing often enables novel and durable strategies to emerge that could not be imagined if the situation is framed in terms of conflicting interests.

Although dialog processes demand substantial time and commitment by participants and may require management by experienced facilitators, we suggest that the understanding, trust, and networks built through dialog processes probably justify greater investment in such activities as a means of stimulating transformation in ecosystem management. Alternatively, as shown in our case studies, dialog processes may be realized by supporting key leaders 
who can lead and support one-on-one meetings between stakeholders in a particular region (e.g., Table 3, Quote F). Therefore, an important area of research flowing from this study is better understanding how stakeholder dialog processes may best be encouraged and supported to the end of stimulating innovation in ecosystem management. An important tool in this regard is social network analysis, or the mapping and measuring of relationships and flows between people, groups, and organizations (Scott 1991, Freeman 2006).

Although it was not employed in the case studies we examined, we also note that scenario planning may be a particularly productive and nonthreatening means by which dialog processes can be realized (van der Heijden 1996, Peterson et al. 2003, Kahane 2004, Scearce et al. 2004). Scenario planning has two additional benefits: (1) it explicitly requires that several alternative futures for a region be considered, encouraging broader framing and scoping of a situation and hence stimulating the generation of a more diverse set of possible management options, and (2) by focusing on the future, it removes participants from immediate conflicts that are often a significant obstacle to initiating dialog (Kofinas and Griggs 1996, Olsson 2007). Exploring the use of scenario planning as a tool in ecosystem-management transformation may be a particularly fruitful area of research.

\section{Provide institutional support}

Our case studies support a substantial body of work (e.g., Born and Genskow 2001, Young Foundation 2006) that points to the importance of institutional support in enabling new ecosystem-management approaches to take root. As noted above, supporting environmental awareness, developing social entrepreneurship, and fostering stakeholder dialog processes can stimulate the formation of groups aimed at collaborative ecosystem management. However, once such groups have formed, their maintenance over time is often seriously challenged by institutional and financial constraints (Wondolleck and Yaffee 2000, Born and Genskow 2001). As noted by other authors (Born and Genskow 2001, Young Foundation 2006), the Kristianstads Vattenrike and Yahara Lakes examples suggest that partnering with local government institutions often provides a durable base from which collaborative ecosystem-management groups can function. However, in many parts of the world, enabling such partnerships requires major changes in how governments operate. In particular, it requires strategies and mechanisms that prioritize creative connections and institutions that cut across traditional boundaries (Young Foundation 2006).

Furthermore, given the complex and multidimensional nature of the issues that collaborative management groups seek to address, the outcomes from the activities of these groups may not be obvious or may only become evident after a substantial period of time. Therefore, Born and Genskow (2001) stress the need for more complex evaluation procedures to assess the performance of such groups. Specifically, assessment should not focus only on environmental outcomes, but should also include measures of social-capacity development, institutional changes, economic outputs, and intermediate environmental outcomes (Born and Genskow 2001). Our case studies further emphasized the importance of fun, informal activities such as field trips and barbequing, in fostering team spirit and innovation (e.g., Table 3, Quote G). Such activities challenge conventional notions of appropriate activities for environmental-management groups and agencies. Therefore, our findings highlight the need to reconsider restrictions associated with funding that aims to support and stimulate innovation in ecosystem management.

We also note that several countries have piloted innovative legislative and institutional arrangements to stimulate the formation of collaborative grassroots ecosystem-management groups. For example, Sweden passed legislation enabling the formation of local fishing associations in the early 1980s. These associations have access to governmental funding, as well as certain legal powers relating to the setting of fishing quotas, and management of land use in the watersheds of the lakes that they manage (Olsson and Folke 2001). At least in some regions, there is evidence that the formation of such associations has stimulated innovative ecosystem-management strategies and has improved environmental conditions (Yaffee et al. 1996, Born and Genskow 2000, Olsson and Folke 2001). Other government-mediated factors that can strongly influence innovation in ecosystem management are: (1) the creation of markets for ecosystem services (Dasgupta 2001, Daily and Ellison 2002), (2) the provision of capital, education, and infrastructure (Homer-Dixon 1995), and political stability (Wright 1991, Homer-Dixon 1995). Central to governmental strategies for stimulating innovation in ecosystem management 
is an acknowledgement that not all funded initiatives will succeed. As in any innovation process, intolerance of failure is likely to stifle innovation in ecosystem management. A detailed comparative analysis of how and under which conditions governmental programs successfully stimulate the formation of collaborative grassroots ecosystem-management groups could provide valuable insights in this regard.

\section{CONCLUSION}

The findings from this exploratory study suggest that a social-innovation perspective provides a useful alternative framework for studying and understanding factors that may promote transformation in ecosystem management. We have suggested several strategies by which innovation in ecosystem management may potentially be enhanced in support of transformation in ecosystem management. However, these findings need to be verified and further explored by more in-depth studies. Understanding obstacles and barriers that hinder transformation in ecosystem management are particularly important, and represent an important area for further research. The insights from this work would also be furthered by in-depth analyses of ecosystem-management transformations at larger regional, national, and international scales, and with respect to environmental attributes other than freshwater.

We note two final issues in relation to social innovation and transformation in ecosystem management. First, innovation is a strongly nonlinear process. Transformative social innovations are often characterized by a protracted period in which new ideas have very limited rates of adoption. However, as in technology adoption, once uptake of social innovations reach a certain level, they may suddenly "take off" so that adoption rates increase dramatically (Rogers 1995). Our analyses suggest that in terms of meeting new social and environmental needs triggered by environmental degradation, two important reasons for lags in ecosystem management transformation are: (1) that it takes time to appreciate the value of the ecological attributes being lost and to establish their likely causes, and (2) that initial responses are typically incremental changes to existing approaches, and only once it is established that such responses are insufficient are more radical and innovative responses sought. Together, these two factors suggest that we should often expect a substantial delay from the time at which environmental degradation becomes apparent to the time at which society reorganizes ecosystem management to address the degradation. One interpretation of the current global environmental situation is that it is precisely in this "lag" phase: environmental degradation is apparent, the value of the ecological attributes being lost is increasingly appreciated, and it is recognized that existing approaches are inadequate (Intergovernmental Panel on Climate Change 2007, Millenium Ecosystem Assessment 2005), but social institutions have not yet reorganized to address the situation. Our objective has been to explore factors that might be leveraged to foster such reorganization in environmentalmanagement approaches.

Second, innovation is always defined relative to a particular context and time. What is new and innovative today is set to become old and the source of new problems in the future. Therefore, we do not espouse integrated, collaborative management as a panacea. Although we concur with authors who maintain that there is enormous scope to expand such forms of management, and that they are likely to help address many important environmental challenges we face today (Cortner and Moote 1999, Wondolleck and Yaffee 2000, Armitage et al. 2007), integrated, collaborative management is not appropriate in all contexts and is certain to generate its own set of problems in time. A critical challenge in ameliorating the emergence of new problems is the design of ecosystem-management institutions that remain innovative and adaptive over time (Gunderson and Holling 2002, Berkes et al. 2003, Chapin et al. 2009). We have not investigated this issue in our analysis, but identify it as an important area for further research. In particular, we note that there is tremendous scope for social innovation to meet ongoing needs for adaptation as ecosystem management evolves in different localities. Creating environments that foster ongoing social innovation is likely to be critical in this respect, and may be usefully informed by understandings gained in the business and science arenas.

Responses to this article can be read online at: http://www.ecologyandsociety.org/voll5/iss2/art9/responses/ 


\section{Acknowledgments:}

We are especially grateful to the interviewees for sharing their insights and experiences: Per Olsson, Sven-Erik Magnusson, Freek Venter, Andrew Deacon, John Magnuson, and Steve Born. We also thank Harry Biggs, Stefanie Freitag, Belinda Reyers, Laurie Barwell, Ken Genskow, Luis Zambrano, Patrick O'Farrell, Paul Lochner, Roy Bengis, Thomas Gyedu-Ababio and Catherine Tucker for information they provided about potential case studies. Elinor Ostrom, Paul West, Dirk Roux, Harry Biggs, Kevin Rogers, Buz Brock, Xavier Basurto, and Duan Biggs are thanked for comments on the draft project plan, and Amy Kamarainen and Nancy Langston for comments on the draft manuscript. Two anonymous reviewers provided helpful comments that much improved the manuscript. Bill Feeny at the Department of Zoology, University of Wisconsin, helped with the development of the figures. Our research time was funded through a Fulbright grant, the North Temperate Lakes Long-Term Ecological Research (LTER) program of the National Science Foundation (NSF), a Swedish Foundation for Strategic Environmental Research (Mistra) grant, the Swedish Research Council (Formas), and the J. W. Mc Connell Family Foundation.

\section{LITERATURE CITED}

Armitage, D., F. Berkes, and N. Doubleday, editors. 2007. Adaptive co-management: collaboration, learning, and multi-level governance. University of British Columbia Press, Vancouver, British Columbia, Canada.

Arthur, B. 2009. The nature of technology: what it is and how it evolves. Free Press, New York, New York, USA.

Berkes, F., J. Colding, and C. Folke, editors. 2003. Navigating social-ecological systems: building resilience for complexity and change. Cambridge University Press, Cambridge, UK.

Berkes, F., and C. Folke, editors. 1998. Linking social and ecological systems. Cambridge University Press, Cambridge, UK.
Bocking, S. 2004. Nature's experts: science, politics, and the environment. Rutgers University Press, New York, New York, USA.

Born, S. M., and K. D. Genskow. 2000. The watershed approach: an empirical assessment of innovation in environmental management. National Academy of Public Administration, Washington, D. C., USA.

Born, S. M., and K. D. Genskow. 2001. Toward understanding new watershed initiatives. A report from the Madison Watershed Workshop, 20-21 July 2000. University of Wisconsin, Madison, Wisconsin, USA.

Born, S. M., and C. Rumery. 1989. Institutional aspects of lake management. Environmental Management 13:1-13.

Bornstein, D. 2004. How to change the world: social entrepreneurs and the power of new ideas. Oxford University Press, New York, New York, USA.

Breen, C. M., H. C. Biggs, M. C. Dent, A. Görgens, J. O'Keeffe, and K. H. Rogers. 1995. Designing a research programme to promote river basin management. Water Science and Technology 32:103-109.

Brock, T.D. 1985. A eutrophic lake: Lake Mendota, Wisconsin. Springer-Verlag, New York, New York, USA.

Brown, L. D. 1991. Bridging organizations and sustainable development. Human Relations 44:807-831.

Burns, J. M. 1978. Leadership. Harper and Row, New York, New York, USA.

Carpenter, S. R. 2003. Regime shifts in lake ecosystems: pattern and variation. International Ecology Institute, Oldendorf/Luhe, Germany.

Carpenter, S. R., and W.A. Brock. 2008. Adaptive capacity and traps. Ecology and Society 13(2): 40. [online] URL: http://www.ecologyandsociety.org/voll3/ iss2/art40/.

Carpenter, S. R., and R. C. Lathrop. 1999. Lake restoration: capabilities and needs. Hydrobiologia 395-396:19-28. 
Carpenter, S. R., R. C. Lathrop, P. Nowak, E. M. Bennett, T. Reed, and P. A. Soranno. 2006. The ongoing experiment: restoration of Lake Mendota and its watershed. Pages 236-256 in J. J. Magnuson, T. K. Kratz and B. J. Benson, editors. Long-term dynamics of lakes in the landscape: long-term ecological research on north temperate lakes. Oxford University Press, Oxford, UK.

Carson, R. 1962. Silent spring. Houghton Mifflin, Boston, Massachusetts, USA.

Carter, L., D. Ulrich, and M. Goldsmith, editors. 2004. Best practices in leadership development and organization change: how the best companies ensure meaningful change and sustainable leadership. Pfeiffer, San Francisco, California, USA.

Chapin, F.S., G.P. Kofinas, and C. Folke, editors. 2009. Principles of ecosystem stewardship: resilience-based natural resource management in a changing world. Springer, New York, New York, USA.

Christensen, C. M., H. Baumann, R. Ruggles, and T. M. Sadtler. 2006. Disruptive innovation for social change. Harvard Business Review December 2006:94-101.

Cohen, M. D., J. G. March, and J. P. Olsen. 1972. A garbage can model of organizational choice. Administrative Science Quarterly 17:1-25.

Constanza, R., L. J. Graumlich, and W. L. Steffen, editors. 2007. Sustainability or collapse? An integrated history and future of people on Earth. MIT Press, Cambridge, Massachusetts, USA.

Cortner, H. J., and M.A. Moote. 1999. The politics of ecosystem management. Island Press, Washington, D.C., USA.

Council for Scientific and Industrial Research (CSIR). 2001. State of the rivers report: Crocodile, Sabie-Sand and Olifants river systems. CSIR, Pretoria, South Africa.

Daily, G. C., and K. Ellison. 2002. The new economy of nature. Island Press, Washington, D.C., USA.

Dasgupta, P. 2001. Human well-being and the natural environment. Oxford University Press, Oxford, UK.

Dietz, T., E. Ostrom, and P. C. Stern. 2003. The struggle to govern the commons. Science 302:19071912.

Ehrlich, P. R. 1968. The population bomb. Ballantine Books, New York, New York, USA.

Eldredge, N., and S. J. Gould. 1972. Punctuated equilibria: an alternative to phyletic gradualism. Pages 82-115 in T. J. M. Schopf, editor. Models in paleobiology. Freeman, Cooper and Company, San Francisco, California, USA.

Fagerberg, J., D. C. Mowery, and R. R. Nelson, editors. 2006. The Oxford handbook of innovation. Oxford University Press, New York, New York, USA.

Folke, C., T. Hahn, P. Olsson, and J. Norberg. 2005. Adaptive governance of social-ecological systems. Annual Review of Environment and Resources 30:441-473.

Freeman, L. 2006. The development of social network analysis. Empirical Press, Vancouver, British Columbia, Canada.

Funtowicz, S. O., and J. R. Ravetz. 1993. Science for the post-normal age. Futures 25:739-755.

Goffman, E. 1974. Frame analysis: an essay on the organization of experience. Harper and Row, New York, New York, USA.

Gowlland-Gualtieri, A. 2007. South Africa's water law and policy framework: implications for the right to water. International Environmental Law Research Centre (IELRC) working paper 2007-03. IELRC, Geneva, Switzerland.

Gray, B. 1989. Collaborating: finding common ground for multiparty problems. Jossey-Bass, San Francisco, California, USA.

Gray, J. 1995. Enlightenment's wake: politics and culture at the close of the modern age. Routledge, London, UK.

Greenleaf, R. K. 1977. Servant leadership: a journey into the nature of legitimate power and greatness. Paulist, Mahwah, New Jersey, USA. 
Gunderson, L. H., and C. S. Holling, editors. 2002. Panarchy: understanding transformations in human and natural systems. Island Press, Washington, D.C., USA.

Hahn, T., P. Olsson, C. Folke, and K. Johansson. 2006. Trust-building, knowledge generation and organizational innovations: the role of a bridging organization for adaptive comanagement of a wetland landscape around Kristianstad, Sweden. Human Ecology 34:573-592.

Hewlett, J. D., and A. R. Hibbert. 1961. Increases in water yield after several types of forest cutting. Quarterly Bulletin of the International Association of Scientific Hydrology 6:5-17.

Holland, J. H. 1999. Emergence: from chaos to order. Basic Books, New York, New York, USA.

Holling, C. S. 2001. Understanding the complexity of economic, ecological, and social systems. Ecosystems 4:390-405.

Holling, C. S., and L. H. Gunderson. 2002. Resilience and adaptive cycles. Pages 25-62 in L. H. Gunderson and C. S. Holling, editors. Panarchy: understanding transformations in human and natural systems. Island Press, Washington, D.C., USA.

Holling, C. S., L. H. Gunderson, and G. D. Peterson. 2002. Sustainability and panarchies. Pages 63-102 in L. H. Gunderson and C. S. Holling, editors. Panarchy: Understanding transformations in human and natural systems. Island Press, Washington, D.C., USA.

Holling, C. S., and G. K. Meffe. 1996. Command and control and the pathology of natural resource management. Conservation Biology 10:328-337.

Homer-Dixon, T. 1995. The ingenuity gap: can poor countries adapt to resource scarcity? Population and Development Review 21:587-612.

House, R., and P. M. Podsakoff. 2003. Leadership effectiveness: past perspectives and future directions for research. Pages 45-82 in J. S. Greenberg, editor. Organizational behavior: the state of the science. Lawrence Erlbaum, Hillsdale, New Jersey, USA.
Intergovernmental Panel on Climate Change (IPCC). 2007. Climate change 2007: synthesis report. Contribution of working groups I, II and III to the fourth assessment report of the Intergovernmental Panel on Climate Change. IPCC, Geneva, Switzerland.

Isaacs, W. 1999. Dialogue and the art of thinking together. Doubleday, New York, New York, USA.

Janssen, M. A., Ö. Bodin, J. M. Anderies, T. Elmqvist, H. Ernstson, R. R. J. McAllister, P. Olsson, and P. Ryan. 2006. Toward a network perspective of the study of resilience in socialecological systems. Ecology and Society 11(1): 15. [online] URL: http://www.ecologyandsociety.org/voll1/ iss $1 / \operatorname{art} 15 /$.

Kahane, A. 2004. Solving tough problems: an open way of talking, listening, and creating new realities. Berrett-Koehler, San Francisco, California, USA.

Kitchell, J. F., editor. 1992. Food web management: a case study of Lake Mendota. Springer-Verlag, New York, New York, USA.

Kofinas, G. P., and J. R. Griggs. 1996. Collaboration and the BC Round Table on the Environment and the Economy: an early-stage analysis of a "better way" of deciding. Environments 23:17-40.

Kuhn, T. S. 1970. The structure of scientific revolutions. Second edition. University of Chicago Press, Chicago, Illinois, USA.

Kvale, S. 1996. Interviews: an introduction to qualitative research interviewing. Sage Publications, Thousand Oaks, California, USA.

Leadbeater, C. 1997. The rise of the social entrepreneur. Demos, London, UK.

Levi-Strauss, C. 1962. La pensée sauvage. Plon, Paris, France.

Levin, S. A. 1998. Ecosystems and the biosphere as complex adaptive systems. Ecosystems 1:431-436.

Lewin, K., R. Lippitt, and R. White. 1939. Patterns of aggressive behavior in experimentally created social climates. Journal of Social Psychology 10:271-301. 
Loorbach, D. 2007. Transition management: new mode of governance for sustainable development. International Books, Utrecht, The Netherlands.

Louv, R. 2008. Last child in the woods: saving our children from nature-deficit disorder. Algonquin Books, Chapel Hill, North Carolina, USA.

Manson, S. M. 2001. Simplifying complexity: a review of complexity theory. Geoforum 32:405414.

Millennium Ecosystem Assessment (MA). 2005. Ecosystems and human well-being: synthesis. A report of the Millennium Ecosystem Assessment. Island Press, Washington, D.C., USA.

Magnusson, S.-E. 1981. Helgeåns nedre sjösystem - något om människors ingrepp under närmare 400 år [The lake system of the lower Helgeå River-the impact of humans over the last 400 years.] Pages 43-52 in B. Cavallin, editor. Skånes Natur 68: Skånes Naturvårdsförbunds Arsskrift 1981. AB Grahns Boktryckeri, Lund, Sweden.

Martin, J. 2007. The meaning of the $21^{\text {st }}$ century: a vital blueprint for ensuring our future. Riverhead Books, New York, New York, USA.

McCauley, C. D., and E. Van Velsor, editors. 2003. The Center for Creative Leadership handbook of leadership development. Jossey-Bass, Somerset, New Jersey, USA.

McKeown, M. 2008. The truth about innovation. Prentice Hall, Old Tappan, New Jersey, USA.

Meadows, D. H., D. L. Meadows, J. Randers, and W. W. Behrens. 1972. The limits to growth. Universe Books, New York, New York, USA.

Miller, D. 1993. The architecture of simplicity. Academy of Management Review 18:116-138.

Nabhan, G. P. 1997. Cultures of habitat: on nature, culture, and story. Counterpoint, Washington, D.C., USA.

Nakamura, L., and S. M. Born. 1993. Substate institutional innovation for managing lakes and watersheds: a Wisconsin case study. Water Resources Bulletin 29:807-821.

Norberg, J., and G. S. Cumming, editors. 2008. Complexity theory for a sustainable future.
Columbia University Press, New York, New York, USA.

O'Keeffe, J., and K. H. Rogers. 2003. Heterogeneity and management of the Lowveld rivers. Pages 447-469 in J. T. du Toit, K. H. Rogers, and H. C. Biggs, editors. The Kruger experience: ecology and management of savanna heterogeneity. Island Press, Washington, D.C., USA.

Olsson, P. 2007. The role of vision in framing adaptive co-management processes: lessons from Kristianstads Vattenrike, southern Sweden. Pages 268-285 in D. Armitage, F. Berkes and N. Doubleday, editors. Adaptive co-management: collaboration, learning and multi-level governance. University of British Columbia Press, Vancouver, British Columbia, Canada.

Olsson, P., and C. Folke. 2001. Local ecological knowledge and institutional dynamics for ecosystem management: a study of Lake Racken Watershed, Sweden. Ecosystems 4:85-106.

Olsson, P., C. Folke, V. Galaz, T. Hahn, and L. Schultz. 2007. Enhancing the fit through adaptive co-management: creating and maintaining bridging functions for matching scales in the Kristianstads Vattenrike Biosphere Reserve, Sweden. Ecology and Society 12(1): 28. [online] URL: http://www.e cologyandsociety.org/vol12/iss1/art28/.

Olsson, P., C. Folke, and T. Hahn. 2004. Socialecological transformation for ecosystem management: the development of adaptive co-management of a wetland landscape in southern Sweden. Ecology and Society 9(4): 2 http://www.ecologyandsociety. org/vol9/iss4/art2.

Olsson, P., L. H. Gunderson, S. R. Carpenter, P. Ryan, L. Lebel, C. Folke, and C. S. Holling. 2006. Shooting the rapids: Navigating transitions to adaptive governance of social-ecological systems. Ecology and Society 11(1): 18. [online] URL: http: //www.ecologyandsociety.org/vol11/iss1/art18/.

Ostrom, E. 2005. Understanding institutional diversity. Princeton University Press, Princeton, New Jersey, USA.

Peterson, G. D., G. S. Cumming, and S. R. Carpenter. 2003. Scenario planning: a tool for conservation in an uncertain world. Conservation Biology 17:358-366. 
Pilkey, O. H., and L. Pilkey-Jarvis. 2007. Useless arithmetic: why environmental scientists can't predict the future. Columbia University Press, New York, New York, USA.

Plowman, D., L. T. Baker, T. Beck, M. Kulkarni, S. Solansky, and D. Travis. 2007. Radical change accidentally: the emergence and amplification of small change. Academy of Management Journal 50:515-543.

Plummer, R., and J. Fitzgibbon. 2004. Comanagement of natural resources: a proposed framework. Environmental Management 33:876885 .

Postel, S., and B. Richter. 2003. Rivers for life: managing water for people and nature. Island Press, Washington, D.C., USA.

Repetto, R., editor. 2006. Punctuated equilibrium and the dynamics of U.S. environmental policy. Yale University Press, New Haven, Connecticut, USA.

Republic of South Africa. 1998. National Water Act, Act 36 of 1998. South Africa.

Roe, G. H., and M. B. Baker. 2007. Why is climate sensitivity so unpredictable? Science 318:629-632.

Rogers, E. M. 1995. Diffusion of innovations. Fourth edition. The Free Press, New York, New York, USA.

Rogers, K. H. 2006. The real river management challenge: integrating scientists, stakeholders and service agencies. River Research and Applications 22:269-280.

Rogers, K. H., D. J. Roux, and H. C. Biggs. 2000. Challenges for catchment management agencies: lessons from bureaucracies, business and resource management. Water SA 26:505-511.

Rotmans, J., R. Kemp, M. van Asselt, F. Geels, G. Verbong, and K. Molendijk. 2000. Transitions and transition management. International Centre for Integrative Studies, University of Maastricht, Maastricht, The Netherlands.

Rubin, H. J., and I. S. Rubin. 1995. Qualitative interviewing: the art of hearing data. Sage Publications, Thousand Oaks, California, USA.
Scearce, D., K. Fulton, and the Global Business Network Community. 2004. What if? The art of scenario thinking for nonprofits. Global Business Network, Emeryville, California, USA.

Schindler, D. W. 2006. Recent advances in the understanding and management of eutrophication. Limnology and Oceanography 51:356-363.

Schultz, L., C. Folke, and P. Olsson. 2007. Enhancing ecosystem management through socialecological inventories: lessons from Kristianstads Vattenrike, Sweden. Environmental Conservation 34:140-152.

Scott, J. 1991. Social network analysis. Sage Publications, London, UK.

Senge, P. M., C. O. Scharmer, J. Jaworski, and B.S. Flowers. 2004. Presence: human purpose and the field of the future. Society for Organizational Learning, Cambridge, Massachusetts, USA.

Smith, R. E., and D. F. Scott. 1992. The effects of afforestation on low flows in various regions of South Africa. Water SA 18:185-194.

Stake, R. E. 1995. The art of case study research. Sage Publications, Thousand Oaks, California, USA.

Steffen, W. L.,A.Sanderson, P. D. Tyson, J. Jäger, P. A. Matson, B. Moore III, F. Oldfield, K. Richardson, H. J. Schellnhuber, B. L. Turner II, and R. J. Wasson. 2004. Global change and the Earth system: a planet under pressure. SpringerVerlag, Berlin, Germany.

Tavris, C., and E. Aronson. 2007. Mistakes were made (but not by me): why we justify foolish beliefs, bad decisions and hurtful acts. Harcourt, Orlando, Florida, USA.

van der Heijden, K. 1996. Scenarios: the art of strategic conversation. Wiley, New York, New York, USA.

Venter, F. J., and A. R. Deacon. 1995. Managing rivers for conservation and ecotourism in the Kruger National Park. Water Science and Technology 32:227-233.

Venter, F. J., R. J. Naiman, H. C. Biggs, and D. J. Pienaar. 2008. The evolution of conservation 
management philosophy: science, environmental change and social adjustments in the Kruger National Park. Ecosystems 11:173-192.

Von Hippel, E. 1988. The sources of innovation. Oxford University Press, Oxford, UK.

Voss, J. P. 2007. Innovation processes in governance: the development of "emissions trading" as a new policy instrument. Science and Public Policy 34:329-43.

Vredenburg, H., and F. R. Westley. 1997. Innovation and sustainability in natural resource industries in Canada. Optimum: The Journal for Public Sector Management 27:32-40.

Walker, B. H., C. S. Holling, S. R. Carpenter, and A. Kinzig. 2004. Resilience, adaptability and tranformability in social-ecological systems. Ecology and Society 9(2): 5. [online] URL: http://w ww.ecologyandsociety.org/vol9/iss2/art5/.

Walker, B. H., and D. Salt. 2006. Resilience thinking: sustaining ecosystems and people in a changing world. Island Press, Washington, D.C., USA.

Walters, C. J. 1986. Adaptive management of renewable resources. Macmillan, New York, New York, USA.

Waltner-Toews, D., J. J. Kay, and N. M. E. Lister, editors. 2008. The ecosystem approach: complexity, uncertainty, and managing for sustainability. Columbia University Press, New York, New York, USA.

Westley, F. 1997. "Not on our watch:" the biodiversity crisis and global collaboration response. Organization and Environment 10:342360.

Westley, F., and H. Vredenburg. 1991. Strategic bridging: the collaboration between environmentalists and business in the marketing of green products. The Journal of Applied Behavioral Science 27:6590.

Westley, F. R., and H. Vredenburg. 1997. Interorganizational collaboration and the preservation of global biodiversity. Organization Science 8:381403 .
Westley, F. R., B. Zimmerman, and M. Q. Patton. 2006. Getting to maybe: how the world is changed. Vintage Canada, Toronto, Ontario, Canada.

Wicht, C. L. 1949. Forestry and water supplies in South Africa. Bulletin 33, Department of Forestry. Government Printer, Pretoria, South Africa.

Wondolleck, J. M., and S. L. Yaffee. 2000. Making collaboration work: lessons from innovation in natural resource management. Island Press, Washington, D.C., USA.

World Bank. 2006. World development indicators. World Bank, Washington, D.C., USA.

Wright, R. 1991. The experiment that failed: why Soviet science collapsed. The New Republic 205:20-25.

Yaffee, S. L., A. F. Phillips, I. C. Frentz, P. W. Hardy, S. M. Maleki, and B. E. Thorpe. 1996. Ecosystem management in the United States: an assessment of current experience. Island Press, Washington, D.C., USA.

Yin, R. K. 1994. Case study research: design and methods. Sage Publications, Thousand Oaks, California, USA.

Young Foundation. 2006. Social innovation: what it is, why it matters, how it can be accelerated. Basingstoke, London, UK.

Ziman, J. 2000. Real science: what it is and what it means. Cambridge University Press, Cambridge, UK. 